\title{
Simulasi Numerik Aliran Fluida Melalui Pipa Berlubang
}

\author{
F. M. Tangdan* dan T. A. Rohmat \\ Departemen Teknik Mesin dan Industri, Fakultas Teknik, Universitas Gadjah Mada. \\ Jl. Grafika No.2, Kompleks UGM, Yogyakarta 55281, Indonesia, \\ Telp. (0274) 521673 \\ e-mail: kondetangdan@gmail.com
}

\begin{abstract}
Abstrak
Salah satu peralatan bawah sumur (sub-surface) yang dipasang saat tahap penyelesaian sumur adalah sand control devices untuk mencegah agar pasir di dalam reservoir tidak ikut terproduksi ke permukaan sumur. Sand control devices sebagian besar menggunakan pipa berlubang (perforated pipe) sebagai base pipe yang terpasang pada lubang sumur (wellbore). Salah satu parameter penting yang mempengaruhi laju alir fluida dari reservoir menuju lubang sumur adalah penurunan tekanan total (total pressure drop). Pipa berlubang memiliki desain yang beragam tergantung dengan kebutuhan di lapangan. Dalam mendesain suatu pipa berlubang maka yang perlu diperhatikan adalah jenis material dan dimensi pipa berlubang, jumlah lubang (perforation density), sudut fasa dan pola distribusi lubang perforasi. Untuk dapat mengetahui perilaku pola aliran (axial and radial inflow) yang melalui pipa berlubang sebagai base pipe dari sand control devices akibat pengaruh sudut fasa perforasi $\left(60^{\circ}, 90^{\circ}, 180^{\circ}\right)$ dan pola distribusi lubang perforasi bentuk staggered dan non-staggered maka dilakukan simulasi numerik menggunakan software ANSYS 18.2. Model turbulen yang digunakan adalah $\mathrm{k}-\varepsilon$ standard dan simulasi dilakukan dengan 5 kondisi flow rate ratio yaitu $0 \%$, $10 \%, 15 \%, 20 \%$ dan 30\%. Hasil simulasi pengaruh sudut fasa lubang perforasi menunjukkan bahwa sudut fasa $60^{\circ}$ memiliki penurunan tekanan total paling rendah dibandingkan dengan dua sudut fasa lainnya. Sedangkan pada pengaruh pola distribusi lubang didapatkan bahwa pola distribusi model non-staggered memiliki penurunan tekanan total paling rendah dibandingkan dengan dua model pola distribusi staggered (screw dan non screw).
\end{abstract}

Kata kunci : Pipa berlubang, radial inflow, penurunan tekanan, sudut fasa, distribusi lubang.

\begin{abstract}
One of sub-surface equipment installed during well completion are sand control devices to prevent sand in the reservoir from being produced to the surface. Sand control devices which installed in the wellbore mostly use perforated pipe as base pipe. One of the important parameters that influence the flow rate of fluid from the reservoir to the wellbore is total pressure drop. Perforated pipe has various designs depending on requirement in the field. In designing a perforated pipe some parameters need to be considered are perforated pipe material and dimension, number of holes (perforation density), perforation phasing and perforation holes distribution pattern. To study the behaviour of fluid flow patterns (axial and radial inflow) through the perforated pipe as a base pipe of sand control devices due to the influence of perforation phasing $\left(60^{\circ}, 90^{\circ}, 180^{\circ}\right)$ and perforation holes distribution pattern in the form of staggered and non-staggered then numerical simulations were performed using ANSYS 18.2 software. Turbulent model used is $k-\varepsilon$ standard and simulation is carried out with 5 flow rate ratio conditions (0\%, 10\%, 15\%, 20\% and 30\%). Simulation results on the effect of perforation phasing show that the phasing angle of $60^{\circ}$ has the lowest total pressure drop compared to the other two phasing angles. While in
\end{abstract}


F. M. Tangdan dan T. A. Rohmat / Journal of Mechanical Design and Testing 3(1), (2021), 29-46

the effect of distribution pattern it is found that the distribution pattern of non-staggered model has the lowest total pressure drop compared to the other two staggered distribution patterns models (screw and non-screw).

Keywords : Perforated pipe, radial inflow, pressure drop, perforation phasing, hole distribution.

\section{PENDAHULUAN}

Dalam industri migas pada sektor hulu produktivitas sumur-sumur minyak adalah hal yang sangat penting bagi keberlangsungan industri. Dari bentuknya secara umum sumur minyak dikategorikan menjadi dua yaitu sumur vertikal dan sumur horisontal. Pada awalnya rata-rata sumur minyak adalah sumur vertikal tetapi dengan berkembangnya teknologi dalam pengeboran sumur maka dapat dilakukan pengeboron lubang secara horisontal. Salah satu keuntungan dari sumur horisontal (horizontal wellbore) adalah memiliki produktivitas yang lebih besar dari pada sumur vertikal karena dapat menjangkau zona produksi minyak atau area reservoir yang lebih banyak dengan satu kali pengeboran. Ilustrasi bentuk sumur vertikal dan horisontal dapat dilihat pada Gambar 1.

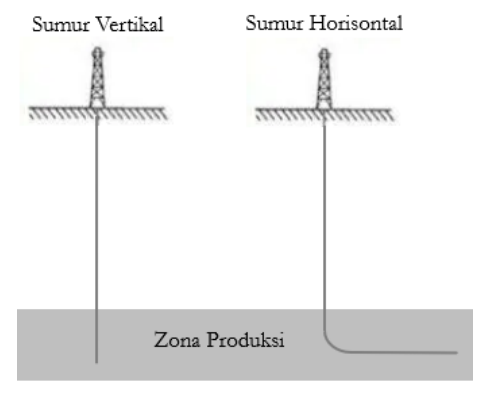

Gambar 1. Ilustrasi sumur vertikal dan horizontal

Setelah pengeboran sumur dilakukan maka tahap selanjutnya adalah pemasangan peralatan bawah sumur (sub-surface). Salah satu peralatan bawah sumur adalah sand control devices yang dipasang pada pada lubang sumur (wellbore) untuk mencegah pasir di reservoir ikut terproduksi ke permukaan bersama fluida reservoir. Contoh sand control devices yang banyak digunakan adalah saringan pasir atau sand screen dengan berbagai model seperti wire-wrapped, woven/sintered wire mesh, gravel pack dan slotted/predrilled liner yang menggunakan pipa berlubang (perforated pipe) sebagai base pipe dari sand control devices. Aliran fluida dari reservoir yang melalui pipa berlubang ke permukaan adalah gabungan dari aliran axial dan aliran radial (radial inflow) seperti yang ditunjukkan pada Gambar 2 dan salah satu parameter yang mempengaruhi laju alir fluida dari reservoir menuju lubang sumur adalah penurunan tekanan total (total pressure drop) yang terjadi pada pipa berlubang.

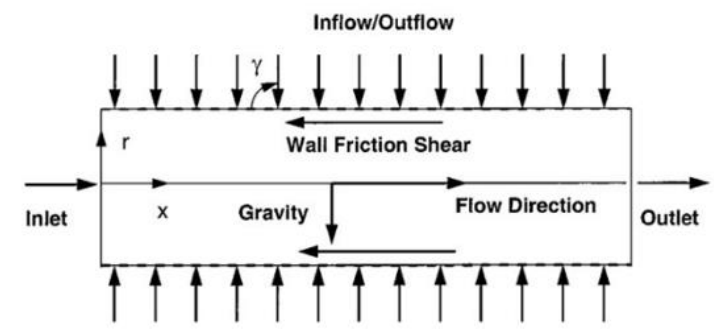

Gambar 2. Aliran fluida pada pipa berlubang (Ouyang dkk, 1998) 
Penelitian mengenai aliran fluida melalui pipa berlubang pada sumur horisontal telah dilakukan oleh peneliti sebelumnya dan ditunjukkan pada Tabel 1.

Tabel 1. Studi eksperimen dan simulasi numerik peneliti sebelumnya

\begin{tabular}{|c|c|c|}
\hline Peneliti & Konfigurasi & Hasil \\
\hline Dikken, 1990 & $\begin{array}{l}\text { Studi eksperimental: model sumur } \\
\text { horizontal. }\end{array}$ & $\begin{array}{l}\text { Penurunan tekanan total yang terjadi hanya } \\
\text { dipengaruhi oleh wall friction. }\end{array}$ \\
\hline $\begin{array}{l}\text { Asheim dkk, } \\
1992\end{array}$ & $\begin{array}{l}\text { Studi eksperimental: Injeksi } \\
\text { langsung ke test pipe sebagai ilustrasi } \\
\text { radial inflow dengan lubang perforasi } \\
\text { berjumlah } 1 \text { dan } 2 \text { (Fluida kerja air). }\end{array}$ & $\begin{array}{l}\text { Selain wall friction, penurunan tekanan total } \\
\text { juga dipengaruhi oleh radial inflow. }\end{array}$ \\
\hline $\begin{array}{c}\text { Su dan } \\
\text { Gudmundsson, } \\
1993\end{array}$ & $\begin{array}{l}\text { Studi eksperimental: Lubang } \\
\text { perforasi ditutup dengan beat } \\
\text { shrinkable tube agar dapat diketahui } \\
\text { friction factor akibat adanya lubang } \\
\text { perforasi. Lubang perforasi } 4,6,8 \& \\
12 \mathrm{SPF} \text { dan sudut fasa } 45^{\circ}, 60^{\circ}, 90^{\circ} \\
\& 120^{\circ} \text { (Fluida kerja air). }\end{array}$ & $\begin{array}{l}\text { Pada saat tidak ada radial inflow, friction factor } \\
\text { tidak dipengaruhi oleh sudut fasa dengan } \\
\text { perforation density (jumlah lubang) yang sama. }\end{array}$ \\
\hline $\begin{array}{c}\text { Su dan } \\
\text { Gudmundsson, } \\
1994\end{array}$ & $\begin{array}{l}\text { Studi eksperimental: Injeksi ke test } \\
\text { pipe melalui pipa selubung sebagai } \\
\text { ilustrasi radial inflow dengan lubang } \\
\text { perforasi } 12 \mathrm{SPF} \text { dan sudut fasa } 60^{\circ} \\
\text { (Fluida kerja air). }\end{array}$ & $\begin{array}{l}\text { Penurunan tekanan total pada pipa } \\
\text { berlubang dibagi menjadi empat komponen } \\
\text { yaitu penurunan tekanan akibat friction, } \\
\text { acceleration, perforation roughness dan mixing } \\
\text { fluids. }\end{array}$ \\
\hline $\begin{array}{c}\text { Su dan } \\
\text { Gudmundsson, } \\
1998\end{array}$ & $\begin{array}{l}\text { Studi eksperimental: Injeksi ke test } \\
\text { pipe melalui pipa selubung sebagai } \\
\text { ilustrasi radial inflow dengan lubang } \\
\text { perforasi } 12 \mathrm{SPF} \text { dan sudut fasa } 60^{\circ} \text {. } \\
\text { Test pipe dibagi menjadi } 2 \text { section yaitu } \\
\text { dengan lubang perforasi dan tanpa } \\
\text { lubang perforasi / partly perforated } \\
\text { pipe (Fluida kerja air). }\end{array}$ & $\begin{array}{l}\text { Penurunan tekanan total pada pipa } \\
\text { berlubang disederhanakan menjadi tiga } \\
\text { komponen yaitu penurunan tekanan akibat } \\
\text { friction, acceleration dan additional (perforation } \\
\text { roughness dan mixing fluids). }\end{array}$ \\
\hline $\begin{array}{l}\text { Ouyang dkk, } \\
1998\end{array}$ & $\begin{array}{l}\text { Studi eksperimental: model sumur } \\
\text { horizontal. }\end{array}$ & $\begin{array}{l}\text { Membuat model untuk aliran satu fasa yang } \\
\text { mewakili penurunan tekanan akibat friction, } \\
\text { acceleration, grafitasi dan inflow. Korelasi baru } \\
\text { terkait wall friction factor juga dibuat untuk } \\
\text { menentukan wall-friction shear dan penurunan } \\
\text { tekanan friction pada aliran inflow (sumur } \\
\text { produksi) dan outflow (sumur injeksi) baik } \\
\text { aliran laminar maupun turbulen. }\end{array}$ \\
\hline $\begin{array}{l}\text { Ouyang dkk, } \\
2009\end{array}$ & $\begin{array}{l}\text { Simulasi numerik: } 1 \text { lubang } \\
\text { perforasi dengan variasi } 3 \text { jarak } \\
\text { posisi lubang dari inlet pipa (Fluida } \\
\text { air). Validasi menggunakan hasil } \\
\text { perhitungan teoritis dengan } \\
\text { perbedaan }-0,83 \%-0.48 \% \text {. }\end{array}$ & $\begin{array}{l}\text { Pipa berlubang dengan radial inflow pada satu } \\
\text { lubang perforasi mempengaruhi aliran fluida } \\
\text { dan penurunan tekanan disepanjang lubang } \\
\text { sumur dan hasilnya bervariasi tergantung } \\
\text { besarnya laju alir radial inflow. Hasil simulasi } \\
\text { menunjukkan semakin besar flow rate ratio } \\
\text { maka semakin besar penurunan tekanan yang } \\
\text { terjadi dan semakin dekat posisi lubang } \\
\text { perforasi dengan sisi outlet pipa maka } \\
\text { semakin kecil pengaruhnya terhadap } \\
\text { penurunan tekanan. }\end{array}$ \\
\hline
\end{tabular}


F. M. Tangdan dan T. A. Rohmat / Journal of Mechanical Design and Testing 3(1), (2021), 29-46

\begin{tabular}{|c|c|c|}
\hline $\begin{array}{l}\text { Abdulwahid } \\
\text { dkk, } 2013\end{array}$ & $\begin{array}{l}\text { Simulasi numerik: } 2 \text { lubang } \\
\text { perforasi posisi berlawanan dan } \\
\text { sudut fasa } 180^{\circ} \text { (Fluida air). Validasi } \\
\text { dengan studi eksperimen peneliti } \\
\text { lain dan hasil simulasi menunjukkan } \\
\text { perilaku aliran fluida yang sama } \\
\text { dengan studi eksperimen. }\end{array}$ & $\begin{array}{l}\text { Semakin besar flow rate ratio maka semakin } \\
\text { besar penurunan tekanan yang terjadi, } \\
\text { semakin banyak lubang perforasi maka } \\
\text { semakin besar wall shear stress pipa dan } \\
\text { perubahan turbulent kinetic energy di dalam pipa } \\
\text { terjadi saat main flow bertabrakan dengan } \\
\text { radial inflow yang melalui lubang perforasi. }\end{array}$ \\
\hline $\begin{array}{l}\text { Abdulwahid } \\
\text { dkk, } 2013\end{array}$ & $\begin{array}{l}\text { Simulasi numerik: Geometri test pipe } \\
\text { dan validasi menggunakan model } \\
\text { eksperimen Su dan Gudmundsson } \\
1998 \text { (Fluida air). Validasi dengan } \\
\text { studi eksperimen Su dan } \\
\text { Gudmundsson, } 1998 \text { dan hasil } \\
\text { simulasi menunjukkan perilaku } \\
\text { aliran fluida yang sama dengan studi } \\
\text { eksperimen. }\end{array}$ & $\begin{array}{l}\text { Semakin besar flow rate ratio dan perforation } \\
\text { density maka semakin besar penurunan } \\
\text { tekanan total yang terjadi. }\end{array}$ \\
\hline $\begin{array}{l}\text { Abdulwahid } \\
\text { dkk, } 2014\end{array}$ & $\begin{array}{l}\text { Simulasi numerik: Variasi } 5 \text { profil } \\
\text { radial inflow (Fluida air). Validasi } \\
\text { dengan model aliran fluida satu fasa } \\
\text { hasil studi eksperimen Ouyang dkk, } \\
1998 .\end{array}$ & $\begin{array}{l}\text { Perilaku wall shear stress pada pipa mengikuti } \\
\text { profil radial inflow yang divariasikan. Semakin } \\
\text { besar radial inflow maka semakin besar wall } \\
\text { shear stress pada pipa. Adanya radial inflow } \\
\text { menyebabkan kenaikan penurunan tekanan } \\
\text { friction tetapi dalam beberapa kondisi radial } \\
\text { inflow dapat menyebabkan penurunan } \\
\text { tekanan friction menjadi berkurang karena } \\
\text { radial inflow memberikan efek lubrikasi. }\end{array}$ \\
\hline $\begin{array}{l}\text { Azadi dkk, } \\
2017\end{array}$ & $\begin{array}{l}\text { Simulasi numerik: Variasi parameter } \\
\text { perforasi yaitu diameter, perforation } \\
\text { density dan sudut fasa lubang } \\
\text { perforasi (Fluida air). Validasi } \\
\text { menggunakan studi eksperimen } \\
\text { Asheim dkk, } 1992 \text { dengan } \\
\text { perbedaan } 9,4 \% \text { dan Ouyang dkk, } \\
1998 \text { dengan perbedaan } 4,7 \% \text {. }\end{array}$ & $\begin{array}{l}\text { Semakin besar perforation density maka } \\
\text { semakin besar wall friction factor, shear stress dan } \\
\text { penurunan tekanannya. Pengaruh diameter } \\
\text { lubang perforasi terhadap penurunan } \\
\text { tekanan tergantung dari rasio diameter } \\
\text { lubang perforasi dan lubang pipa. Selain itu } \\
\text { hasil simulasi juga membuktikan jika wall } \\
\text { friction factor adalah independent terhadap sudut } \\
\text { fasa (perforating phasing dan penurunan } \\
\text { tekanan total dipengaruhi oleh flow rate ratio. }\end{array}$ \\
\hline $\begin{array}{l}\text { Salim dkk, } \\
\qquad 2017\end{array}$ & $\begin{array}{l}\text { Simulasi numerik: } 2 \text { lubang } \\
\text { perforasi dengan variasi parameter } \\
\text { perforasi dan variasi bentuk lubang } \\
\text { perforasi silinder dan kerucut } \\
\text { (Fluida air). Validasi menggunakan } \\
\text { simulasi numerik Abdulwahid dkk, } \\
2013 \text { dengan perbedaan kurang dari } \\
\text { 2\% (Fluent) dan 5\% (CFX). }\end{array}$ & $\begin{array}{l}\text { Semakin besar diameter lubang perforasi dan } \\
\text { radial inflow maka semakin besar penurunan } \\
\text { tekanan yang terjadi. Bentuk lubang perforasi } \\
\text { silinder memiliki penurunan tekanan yang } \\
\text { lebih besar daripada bentuk kerucut dengan } \\
\text { parameter perforasi yang sama dan panjang } \\
\text { lubang perforasi memiliki pengaruh yang } \\
\text { sangat kecil terhadap penurunan tekanan } \\
\text { sehingga dapat diabaikan. }\end{array}$ \\
\hline $\begin{array}{l}\text { Jianguang dkk, } \\
2017\end{array}$ & $\begin{array}{l}\text { Studi eksperimental: Injeksi melalui } \\
\text { pipa selubung dengan variasi } \\
\text { diameter lubang perforasi, perforation } \\
\text { density } 8,6 \text { \& } 12 \text { SPM dan sudut fasa } \\
45^{\circ}, 90^{\circ} \& 180^{\circ} \text { (Fluida mineral oil). }\end{array}$ & $\begin{array}{l}\text { Mengembangkan model penurunan tekanan } \\
\text { akibat friction dan mixing fluids pada aliran } \\
\text { satu fasa yang melalui pipa berlubang dengan } \\
\text { hasil akurasi secara berturut-turut adalah } 4 \% \\
\text { dan 3\% sementara untuk penurunan tekanan } \\
\text { total memiliki akurasi } 2 \% \text { dari hasil } \\
\text { eksperimen yang dilakukan }\end{array}$ \\
\hline
\end{tabular}


F. M. Tangdan dan T. A. Rohmat / Journal of Mechanical Design and Testing 3(1), (2021), 29-46

\begin{tabular}{|c|l|l|}
\hline $\begin{array}{c}\text { Rashad dkk, } \\
2018\end{array}$ & $\begin{array}{l}\text { Simulasi numerik: Perbandinggan } \\
\text { geometri pipa berlubang antara 400 }\end{array}$ & $\begin{array}{l}\text { Sudut } 90^{\circ} \text { memiliki penurunan tekanan total } \\
\text { lebih besar dari sudut } 180^{\circ} .\end{array}$ \\
& $\begin{array}{l}90^{\circ} \text { dan } 200 \text { lubang perforasi dengan sudut fasa } \\
\text { dengan } 180^{\circ} \text { (Fluida air). }\end{array}$ & \\
\hline
\end{tabular}

Studi yang dilakukan sebelumnya hanya menggunakan parameter sudut fasa untuk mengambarkan distribusi lubang perforasi yang memiliki jumlah lubang lebih dari satu. Selain parameter sudut fasa dalam desain pipa berlubang juga memiliki pola distribusi lubang yang tersebar pada dinding pipa yaitu pola staggered dan non-staggered. Studi ini difokuskan pada perilaku aliran fluida seperti yang ditunjukkan pada Gambar 2 yaitu aliran axial dan radial inflow yang melalui pipa berlubang sebagai base pipe dari sand screen dengan melakukan pengamatan pada pengaruh sudut fasa perforasi yang banyak digunakan yaitu pada sudut fasa $60^{\circ}, 90^{\circ}$ dan $180^{\circ}$. Pengamatan juga dilakukan pada pengaruh pola distribusi lubang perforasi (staggered dan nonstaggered) terhadap penurunan tekanan total yang terjadi yang belum pernah dilakukan studi berdasarkan penelitian yang ditunjukkan pada Tabel 1 sehingga diharapkan dapat mempeoleh desain pipa berlubang yang lebih baik.

\section{METODE PENELITIAN}

Pada studi ini simulasi numerik akan dilakukan dengan menggunakan software ANSYS workbench 18.2 mulai dari pembuatan geometri, meshing dan komputasi dengan asumsi aliran fluida adalah satu fasa, steady state dan incompressible pada kondisi isotermal. Fluida yang digunakan adalah air dengan densitas 998,2 kg/m³ dan viskositas dinamik 0,001 kg/m.s. Geometri yang dibuat pada aplikasi ANSYS design modeler adalah geometri domain fluida yang akan dilakukan komputasi sehingga geometri yang dibuat bukan dimensi aktual dari pipa berlubang yang memiliki lubang-lubang perforasi. Pada Gambar 3 bentuk silinder kecil di sekeliling dinding pipa bagian luar adalah domain fluida lubang perforasi dengan ketebalan silinder sama dengan tebal pipa. Konfigurasi geometri dari pipa berlubang disajikan pada Tabel 2.

Tabel 2. Konfigurasi geometri pipa berlubang

\begin{tabular}{|c|c|c|c|c|c|c|}
\hline $\begin{array}{c}\text { Model } \\
\text { konfigurasi }\end{array}$ & $\begin{array}{c}\text { Diameter } \\
\text { pipa } \\
(\mathrm{mm})\end{array}$ & $\begin{array}{c}\text { Panjang } \\
\text { Pipa } \\
(\mathrm{mm})\end{array}$ & $\begin{array}{l}\text { Diameter } \\
\text { lubang } \\
\text { Perforasi } \\
(\mathrm{mm})\end{array}$ & $\begin{array}{l}\text { Perforation } \\
\text { density } \\
\text { (Shootper } \\
\text { meter) }\end{array}$ & $\begin{array}{c}\text { Sudut } \\
\text { fasa } \\
\text { perforasi, } \\
\Phi \text { (deg) }\end{array}$ & $\begin{array}{l}\text { Pola Distribusi } \\
\text { Lubang }\end{array}$ \\
\hline 1 & \multirow{3}{*}{100} & \multirow{3}{*}{1000} & \multirow{3}{*}{10} & \multirow{3}{*}{24} & $60^{\circ}$ & \multirow{3}{*}{ Staggered (Screw) } \\
\hline 2 & & & & & $90^{\circ}$ & \\
\hline 3 & & & & & $180^{\circ}$ & \\
\hline & & & & & & \\
\hline 4 & \multirow{3}{*}{100} & \multirow{3}{*}{1000} & \multirow{3}{*}{10} & \multirow{3}{*}{24} & \multirow{3}{*}{$90^{\circ}$} & Staggered (Screw) \\
\hline 5 & & & & & & Staggered (Non-Screw) \\
\hline 6 & & & & & & Non-Staggered \\
\hline
\end{tabular}




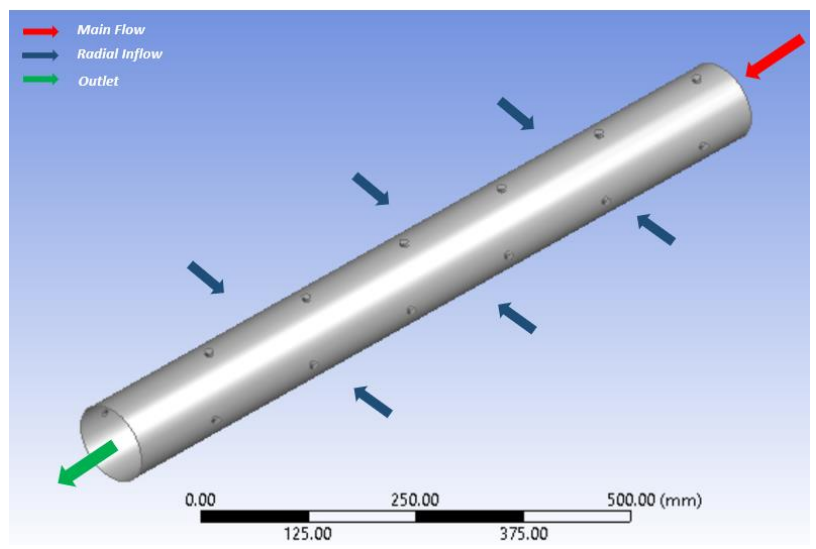

Gambar 3. Geometri pipa berlubang

Model turbulen yang digunakan pada simulasi ini adalah $\mathrm{k}-\varepsilon$ standard karena dari perbandingan hasil penurunan tekanan untuk 5 model turbulen yaitu $\mathrm{k}-\varepsilon$ standard, RNG, $\mathrm{k}-\varepsilon$ realizable, $\mathrm{k}-\omega$ standard dan Reynolds stress model (RSM) menunjukkan bahwa model k- $\mathrm{\varepsilon}$ standard memberikan hasil yang paling akurat sedangkan RSM memberikan hasil yang cukup dapat diterima dengan pertimbangan waktu komputasi yang lebih lama (Azadi dkk, 2017). Boundary condition adalah velocity-inlet untuk kedua inlet (axial dan radial inflow) dan pressure-outlet. Sedangkan solution method yang digunakan adalah metode SIMPLE (Semi-implicit method pressure-linked equations). Dengan asumsi aliran fluida yang digunakan adalah fluida satu fasa, steady state dan incompressible maka persamaan pembentuk aliran yang mengatur proses fisik aliran fluida pada kondisi ini adalah hukum konservasi massa dan konservasi momentum.

\subsection{Model Matematika}

Penurunan tekanan total pada pipa berlubang dengan profil radial inflow adalah seragam di sepanjang lubang sumur dapat dituliskan menjadi:

$$
\Delta P_{T}=\Delta P_{f}+\Delta P_{a c c .}+\Delta P_{g}+\Delta P_{\text {mix }}
$$

Dengan $\Delta P_{T}=$ penurunan tekanan total $(\mathrm{Pa}), \Delta P_{f}=$ penurunan tekanan friction $(\mathrm{Pa}), \Delta P_{\text {acc. }}=$ penurunan tekanan acceleration $(\mathrm{Pa}), \Delta P_{g}=$ penurunan tekanan gravitational $(\mathrm{Pa}), \Delta P_{\text {mix }}=$ penurunan tekanan mixing fluids $(\mathrm{Pa})$. Penurunan tekanan yang disebabkan oleh efek gravitasi pada sumur horisontal diabaikan sehingga Persamaan (1) menjadi:

$$
\Delta P_{T}=\Delta P_{f}+\Delta P_{a c c .}+\Delta P_{\text {mix }}
$$

Untuk masing-masing komponen penurunan tekanan pada Persamaan (2) secara berturut-turut dituliskan sebagai berikut:

$$
\Delta P_{f}=f_{w} \frac{\rho u^{2} \Delta L}{2 D}
$$

Dengan $f_{w}=$ wall friction factor, $\rho=$ densitas $\left(\mathrm{kg} / \mathrm{m}^{3}\right), u=$ kecepatan alir $(\mathrm{m} / \mathrm{s}), \Delta L=$ panjang pipa (m), $D=$ diameter pipa (m). Kemudian untuk komponen penurunan tekanan acceleration yang hanya dipengaruhi oleh densitas dan kecepatan alir fluida dituliskan pada Persamaan (4).

$$
\Delta P_{\text {acc. }}=\rho\left(u_{2}^{2}-u_{1}^{2}\right)
$$

Dengan $u_{1}=$ kecepatan alir di inlet pipa $(\mathrm{m} / \mathrm{s}), u_{2}=$ kecepatan alir di outlet pipa (m/s). Reynolds number dan Darcy friction factor (Haaland, 1983) diperoleh dari Persamaan (5) dan (6). Sehingga wall friction factor pada Persamaan (3) yang diperoleh dari hasil eksperimen Su dan Gudmundsson 1993 dihitung menggunakan Persamaan (7). 


$$
\begin{aligned}
& R_{e}=\frac{\rho u D}{\mu} \\
& f_{D}=\left[-1,8 \log \left(\frac{6,9}{R_{e}}+\left(\frac{\varepsilon}{3,7 D}\right)^{1.11}\right)\right]^{-2} \\
& \sqrt{\frac{8}{f_{w}}}-\sqrt{\frac{8}{f_{D}}}+0.1778 n \frac{d}{D}=1,25 \ln \left(\frac{f_{w}}{f_{D}}\right)
\end{aligned}
$$

Dengan $R_{e}=$ Reynolds number, $\rho=$ densitas $\left(\mathrm{kg} / \mathrm{m}^{3}\right), u=$ kecepatan alir $(\mathrm{m} / \mathrm{s}), D=$ diameter pipa (m), $\mu$ = viskositas dinamik (Pa.s), $f_{D}=$ Darcy friction factor, ${ }^{\varepsilon} / D=$ relative roughness, $n=$ perforation density (SPM), $d=$ diameter lubang perforasi (m).

Komponen mixing fluids adalah penurunan tekanan yang terjadi karena adanya interaksi antara main flow (axial) dan radial inflow di dekat dinding pipa berlubang yang menyebabkan ganguan pada boundary layer dari main flow sehingga mempengaruhi penurunan tekanan total yang terjadi. Karena penurunan tekanan mixing adalah variabel yang sangat komplek maka untuk dapat mengetahui besarnya penurunan tekanan mixing adalah penurunan tekanan total dari hasil simulasi atau ekperimen dikurangi dengan penurunan tekanan friction dan penurunan tekanan acceleration (Su dan Gudmundsson 1998).

\subsection{Meshing}

Proses meshing dilakukan menggunakan aplikasi mesh yang sudah termasuk dalam paket software ANSYS. Tipe mesh adalah mesh tetrahedron seperti yang ditunjukkan pada Gambar 4. Proses meshing sangat mempengaruhi hasil akhir dari suatu simulasi, sehingga grid independence test dilakukan untuk mendapatkan minimum jumlah node dan cell agar dapat mengurangi beban komputasi dengan parameter input dan output secara berturut-turut adalah variasi ukuran mesh dan penurunan tekanan. Hasil grid independence test menunjukkan untuk ukuran mesh diatas 600000 tidak ada perubahan penurunan tekanan yang signifikan sehingga dipilih mesh dengan jumlah node 110682 dan jumlah elemen 566413. Dari hasil grid independence test yang telah dipilih kemudian dilakukan pengecekan kualitas mesh. Hasil kualitas mesh menunjukkan nilai rata-rata 0,22986 (excellent) untuk skewness dan 0,76843 (very good) untuk orthogonal quality.
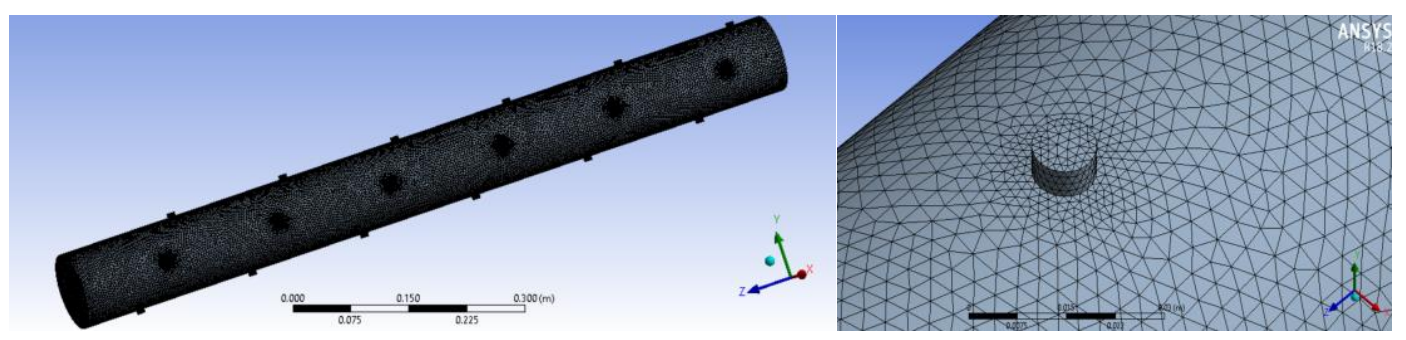

Gambar 4. Tipe mesh tetrahedron pada pipa berlubang

\subsection{Validasi}

Baseline pipa berlubang yang digunakan untuk validasi adalah pipa berlubang dengan panjang $1000 \mathrm{~mm}$, diameter pipa $100 \mathrm{~mm}$, diameter lubang perforasi $10 \mathrm{~mm}$, Sudut fasa $90^{\circ}$, perforation density 24 SPM dan pola distribusi lubang staggered (model screw). Validasi dilakukan dengan variasi kecepatan inlet pada main flow yaitu $0,75 \mathrm{~m} / \mathrm{s}, 3 \mathrm{~m} / \mathrm{s}$ dan $4,5 \mathrm{~m} / \mathrm{s}$ dan radial inflow pada flow rate ratio $0 \%, 10 \%, 15 \%, 20 \%$ dan 30\% dimana flow rate ratio adalah rasio total radial inflow rate terhadap main flow rate. Langkah validasi dilakukan dengan membandingkan penurunan tekanan hasil simulasi terhadap hasil perhitungan menggunakan persamaan empiris hasil studi eksperimental 
seperti yang diuraikan pada sub bab 2.1 model matematika. Untuk memperkuat hasil validasi, maka validasi juga dilakukan dengan menambahkan 2 model dari hasil studi eksperimen peneliti lain yang dituliskan sebagai berikut:

- Model Asheim dkk, 1992.

$$
\begin{aligned}
& f_{p}=4 D \frac{q_{L}}{Q}+2 \frac{D}{n}\left(\frac{q_{L}}{Q}\right)^{2} \\
& -\frac{d p}{d x}=\left(f_{D}+f_{p}\right) \frac{\rho u^{2}}{2 D}
\end{aligned}
$$

Dengan $f_{D}+f_{p}=$ apparent friction factor, $f_{p}=$ perforated friction factor, $q_{L}=$ Inflow rate per length unit $\left(\mathrm{m}^{2} / \mathrm{s}\right), Q=$ Laju alir volume di dalam pipa $\left(\mathrm{m}^{3} / \mathrm{s}\right)$.

- Model Ouyang dkk, 1998.

$$
\begin{aligned}
& R_{e w}=\frac{\rho q_{L}}{\pi \mu} \\
& f_{F}=\frac{1}{4} f_{D} \\
& f_{w}=f_{F}\left(1+0.04304 R_{e w}^{0.6142}\right) \rightarrow \text { Laminer } \\
& =f_{F}\left(1-0.0153 R_{e w}^{0.3978}\right) \rightarrow \text { Turbulen } \\
& -\frac{d p}{d x}=f_{w} \frac{2 \rho u^{2}}{D}+2 \rho u \frac{q_{L}}{A}
\end{aligned}
$$

Dengan $R_{e w}=$ wall Reynolds number, $f_{F}=$ Fanning friction factor, $A=$ luas penampang pipa $\left(\mathrm{m}^{2}\right)$. Hasil validasi ditunjukkan pada Gambar 5 dan memperlihatkan hasil yang cukup akurat yaitu perbandingan hasil simulasi terhadap hasil perhitungan teoritis memiliki perbedaan ratarata $\pm 10 \%$. Selanjutnya simulasi akan dilanjutkan dengan memvariasikan parameter perforasi yaitu sudut fasa dan pola distribusi lubang perforasi sesuai dengan konfigurasi geometri pipa berlubang yang ditunjukkan pada Tabel 1.

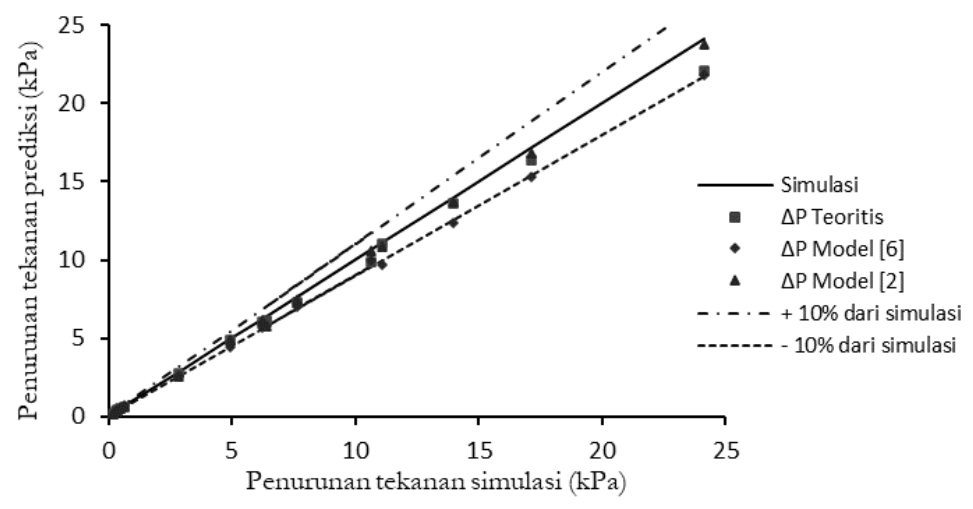

Gambar 5. Grafik hasil validasi

Setelah dilakukan validasi maka langkah selanjutnya adalah melakukan simulasi dengan memvariasikan parameter perforasi yaitu sudut fasa dan pola distribusi lubang perforasi sesuai dengan konfigurasi geometri pipa berlubang yang ditunjukkan pada Tabel 2. Untuk mengetahui 
pengaruh sudut fasa dan pola distribusi lubang perforasi terhadap penurunan tekanan total, simulasi dilakukan dengan kecepatan inlet pada main pipe adalah $3 \mathrm{~m} / \mathrm{s}$ dan lima kondisi radial inflow yaitu pada flow rate ratio $0 \%, 10 \%, 15 \%, 20 \%$ dan $30 \%$.

\section{HASIL DAN PEMBAHASAN}

\subsection{Variasi Sudut Fasa}

Sudut fasa yang dipilih adalah $60^{\circ}, 90^{\circ}$ dan $180^{\circ}$ dengan pola distribusi lubang staggered seperti yang ditunjukkan pada Tabel 2. Jarak antar lubang mulai dari ujung pipa adalah sama besar pada masing-masing baris lubang dan posisi lubang adalah model screw pada masingmasing geometri yang ditunjukkan pada Gambar 6 .

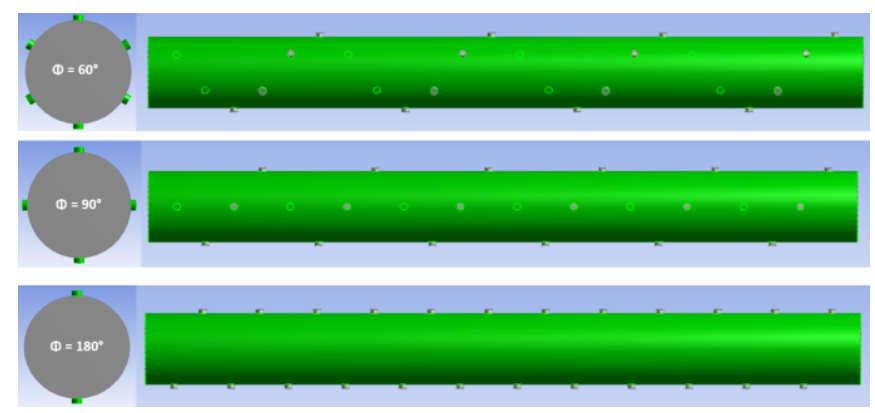

Gambar 6. Sudut fasa lubang perforasi

Pada kondisi tidak ada radial inflow (flow rate rasio $0 \%$ ) pipa berlubang memiliki penurunan tekanan yang sedikit lebih tinggi dari pipa biasa (ordinary pipe). Penurunan tekanan total pada kondisi ini dipengaruhi oleh hambatan yang disebabkan oleh adanya rongga dari lubang perforasi pada dinding pipa atau disebut sebagai perforation roughness seperti yang ditunjukkan pada Gambar 7. Lubang perforasi berperan sebagai kekasaran tambahan di dinding pipa dan kekasaran tambahan ini tergantung juga pada kedalaman lubang perforasi atau ketebalan pipa. Simulasi ditambahkan untuk mengetahui perbandingan penurunan tekanan total pada pipa biasa dan pipa berlubang dengan perforation density 24 SPM. Variasi kecepatan inlet (axial flow) pada pipa adalah $0,75 \mathrm{~m} / \mathrm{s}, 3 \mathrm{~m} / \mathrm{s}$ dan $4,5 \mathrm{~m} / \mathrm{s}$ (tanpa radial inflow).

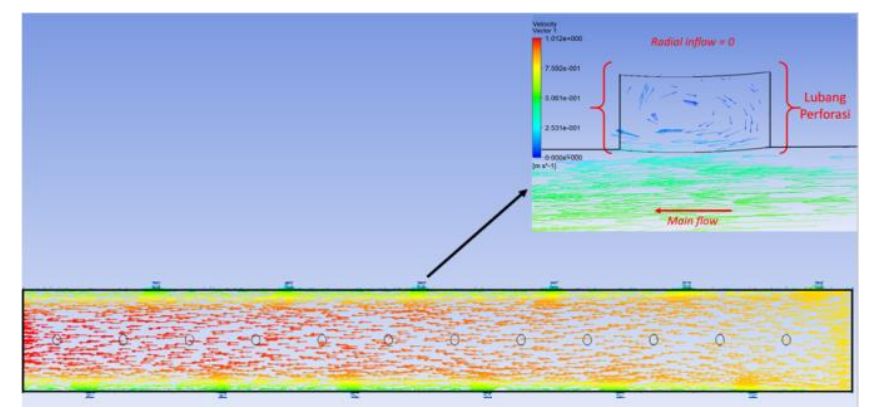

Gambar 7. Vektor kecepatan (main flow) melalui lubang perforasi 


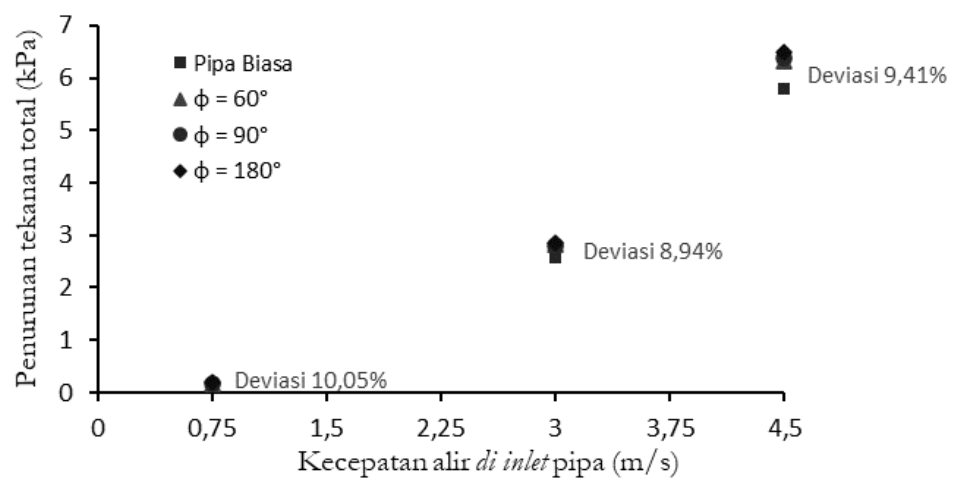

Gambar 8. Perbandingan pipa biasa dan pipa berlubang (tanpa radial inflow)

Gambar 8 memperlihatkan bahwa ketika tidak ada radial inflow maka penurunan tekanan total pada pipa berlubang dengan sudut fasa $60^{\circ}, 90^{\circ}$ dan $180^{\circ}$ lebih tinggi daripada pipa biasa. Perbedaan (deviasi) penurunan tekanan total antara pipa berlubang dengan pipa biasa pada ketiga kondisi kecepatan inlet main flow secara berturut-turut adalah 10,05\%, 8,94\% dan 9,41\%. Selain itu dapat dilihat juga khusus pada pipa berlubang untuk ketiga sudut fasa memiliki perbedaan penurunan tekanan yang saling berdekatan atau rata-rata sebesar $0,08 \%$ sehingga friction factor tidak dipengaruhi oleh sudut fasa dengan perforation density yang sama dan perilaku ini sesuai dengan hasil studi eksperimen Su dan Gudmundsson 1993. Pengaruh sudut fasa terhadap penurunan tekanan friction, acceleration dan mixing fluids untuk lima kondisi flow rate ratio ditunjukkan pada Gambar 9.

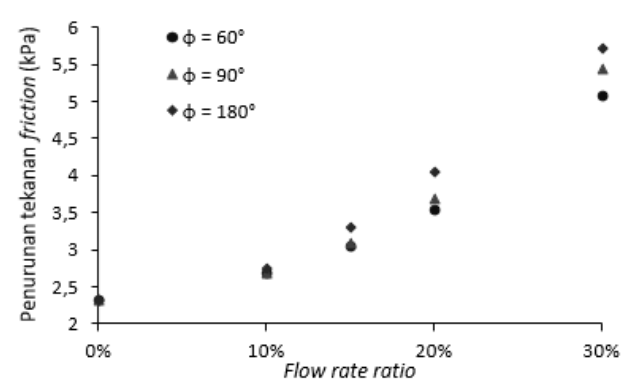

a. Grafik penurunan tekanan friction.

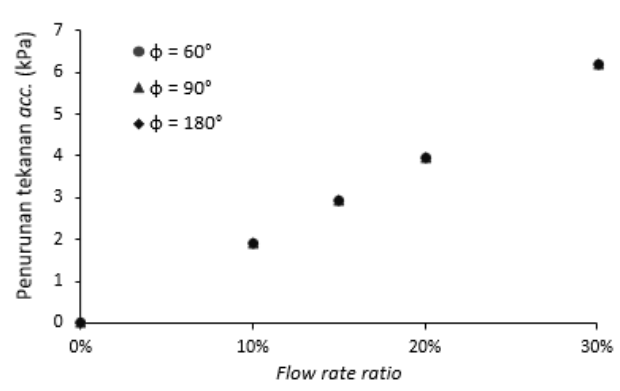

b. Grafik penurunan tekanan acceleration.

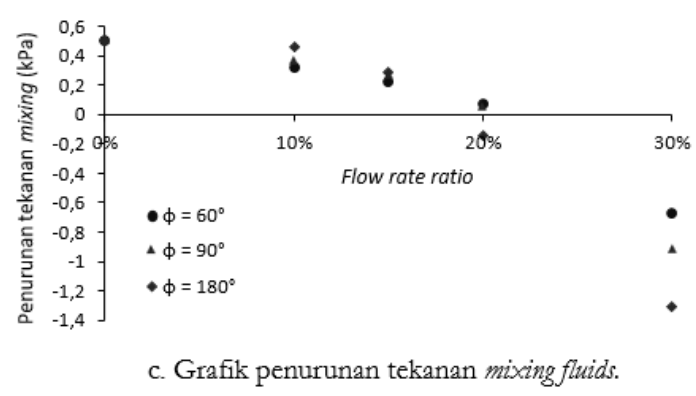

Gambar 9. Penurunan tekanan friction, acceleration dan mixing fluids pada variasi sudut fasa 
Pada Gambar 9a untuk grafik penurunan tekanan friction menunjukkan bahwa semakin besar flowrate ratio maka semakin besar penurunan tekanan friction dan pada flow rate ratio yang sama semakin besar sudut fasa maka penurunan tekanan friction semakin besar dan perilaku ini sama dengan hasil eksperimen Jianguang dkk, 2017. Sudut fasa $180^{\circ}$ memiliki wall shear stress paling tinggi karena kecepatan terbesar akibat adanya radial inflow pada sudut ini terjadi pada kedua sisi pipa yang tidak terdapat lubang perforasi sedangkan sudut fasa $60^{\circ}$ dan $90^{\circ}$ kecepatan terbesar terjadi di tengah pipa berlubang karena radial inflow melalui lubang perforasi yang berada hampir di sekeliling pipa sehingga wall shear stress menjadi lebih rendah. Kontur dan vektor kecepatan di sisi outlet pada masing-masing sudut fasa dapat dilihat pada Gambar 10 dengan salah satu contoh pada flow rate ratio $15 \%$. Friction factor diperoleh dari wall shear stress rata-rata hasil simulasi seperti yang dilakukan oleh Abdulwahid dkk, 2014 dan dihitung menggunakan Persamaan 14.

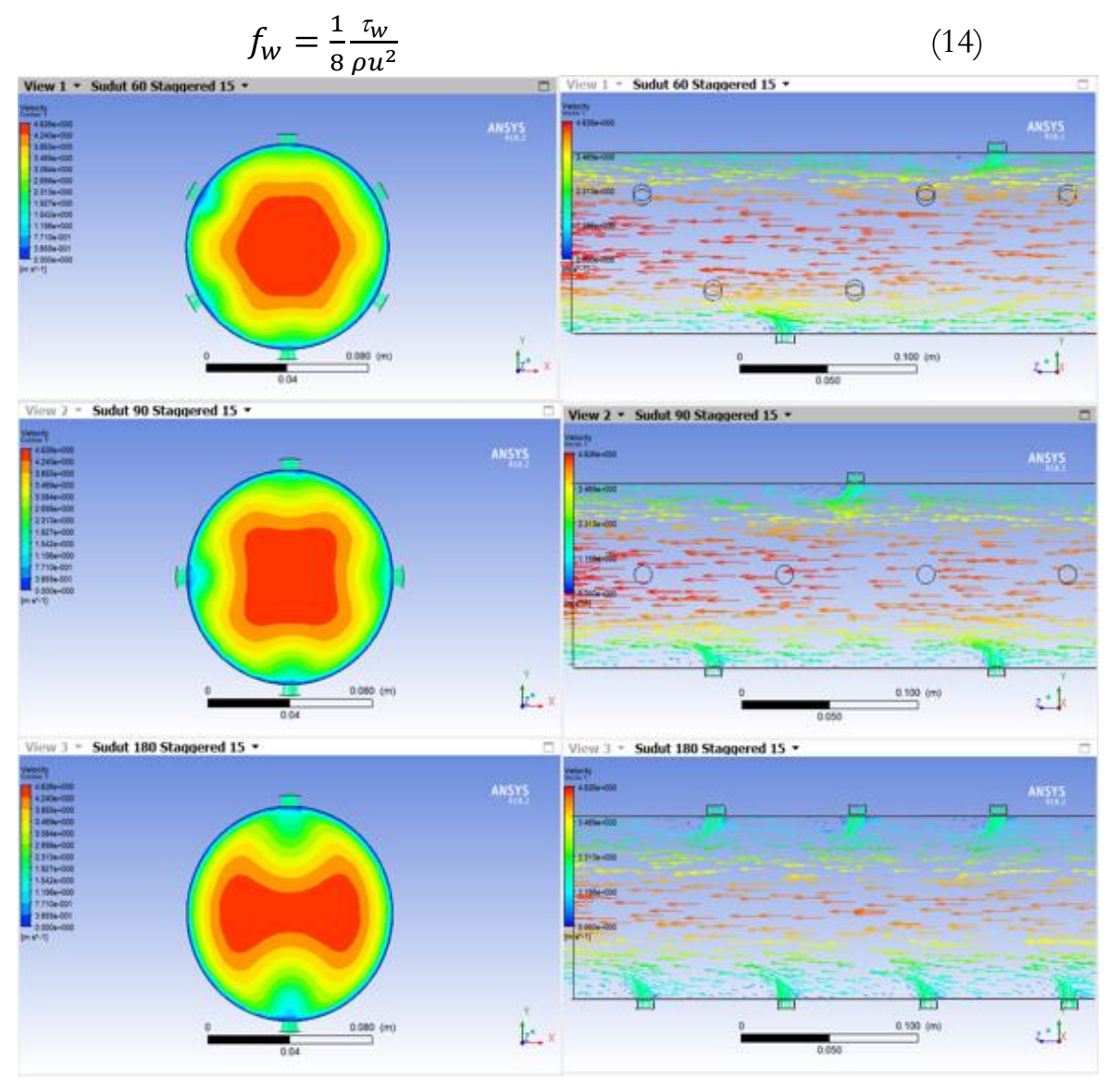

Gambar 10. Kontur dan vektor kecepatan di outlet pipa pada ketiga sudut fasa

Dengan $\tau_{w}=W$ all shear stress $(\mathrm{Pa})$. Pengaruh sudut fasa terhadap penurunan tekanan acceleration pada Gambar 9b adalah linear terhadap flow rate ratio dan bernilai sama untuk semua sudut fasa karena penurunan tekanan acceleration terjadi akibat perubahan momentum yang hanya dipengaruhi oleh densitas dan kecepatan fluida. Pada saat tidak ada radial inflow (flow rate ratio $0 \%$ ) penurunan tekanan acceleration akan bernilai nol untuk fluida incompressible pada pipa yang memiliki diameter dalam konstan. 
Pada Gambar 9c pengaruh sudut fasa terhadap penurunan tekanan mixing fluids pada flow rate ratio $0 \%$ penurunan tekanan hanya dipengaruhi oleh perforation roughness karena tidak ada radial inflow dan pada flow rate ratio sekitar 20\% penurunan tekanan hampir bernilai nol dan pengaruh perforation roughness pada titik ini menjadi berkurang karena efek lubrikasi (smoothing effect) akibat adanya radial inflow. Flow rate ratio ketika penurunan tekanan bernilai nol disebut critical limit dan nilai critical limit tergantung dari geometri pipa berlubang dan flow rate ratio. Ketika flow rate rasio melewati critical limit maka penurunan tekanan akibat efek mixing fluids akan bernilai negatif sehingga akan menurunkan penurunan tekanan total yang terjadi pada pipa berlubang (Su dan Gudmundsson, 1998). Fenomena efek mixing fluids secara jelas dapat dilihat pada streamline kecepatan Gambar 11.

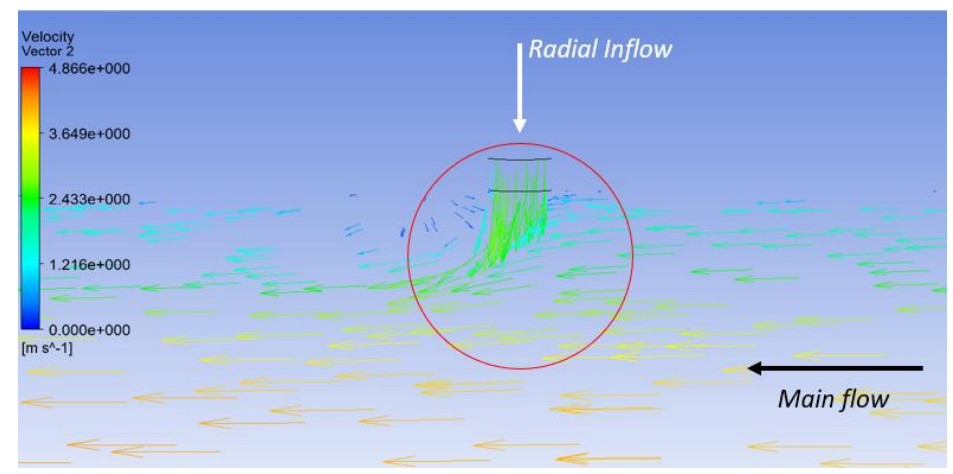

Gambar 11. Efek mixing fluids pada aliran axial dan radial inflow

Pada Gambar 11 terlihat bahwa radial inflow membuat main flow didekat dinding pipa tertahan pada sisi hulu (upstream) dari lubang perforasi sehingga tabrakan aliran antara radial inflow dan main flow (mixing fluids) ini menyebabkan penurunan kecepatan alir main flow di sisi hulu dan hilir (downstream) dari lubang perforasi. Kondisi ini yang disebut sebagai efek lubrikasi pada main flow didekat dinding pipa yang terdapat lubang perforasi akibat adanya penetrasi radial inflow dan efek lubrikasi ini sesuai dengan hasil eksperimen Su dan Gudmundsson, 1998 dan simulasi numerik yang dilakukan oleh Abdulwahid dkk, 2014. Perilaku ini menyebabkan penurunan tekanan menjadi berkurang di sepanjang dinding pipa yang terdapat lubang perforasi terutama pada sudut fasa $180^{\circ}$ yang jarak lubang perforasinya berdekatan karena hanya terdapat pada 2 sisi dinding pipa yang saling berlawanan. Semakin mendekati sisi outlet pipa berlubang maka penetrasi radial inflow akan semakin besar karena terjadi penurunan kecepatan main flow pada tiaptiap lubang perforasi sebelumnya mulai dari lubang perforasi pertama di sisi inlet pipa berlubang. Perubahan kecepatan yang terjadi juga akan mempengaruhi wall shear stress pada pipa berlubang. Pada Gambar 12 menunjukkan penurunan tekanan total akibat pengaruh radial inflow pada semua sudut fasa adalah linear terhadap flow rate ratio dan semakin besar sudut fasa maka semakin besar penurunan tekanan total yang terjadi kecuali pada flow rate ratio 30\% dimana penurunan tekanan total sudut fasa $180^{\circ}$ terlihat lebih rendah walaupun sudut fasa $180^{\circ}$ memiliki penurunan tekanan friction yang lebih tinggi dibanding dua sudut fasa lainnya. Hal ini dikarenakan penurunan tekanan mixing fluids untuk sudut fasa $180^{\circ}$ memiliki nilai paling rendah ketika melewati critical limit yaitu pada flow rate ratio 30\% seperti yang ditunjukkan pada Gambar 9c sehingga efek mixing akibat radial inflow mengindikasikan bahwa penurunan tekanan mixing mengurangi penurunan tekanan total yang terjadi. 


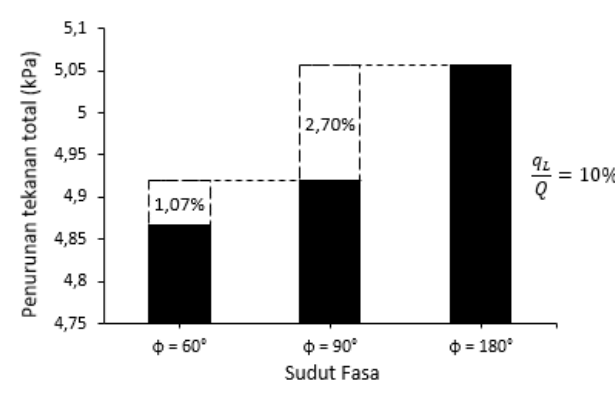

a. Penurunan tekanan total pada flow rate ratio $10 \%$

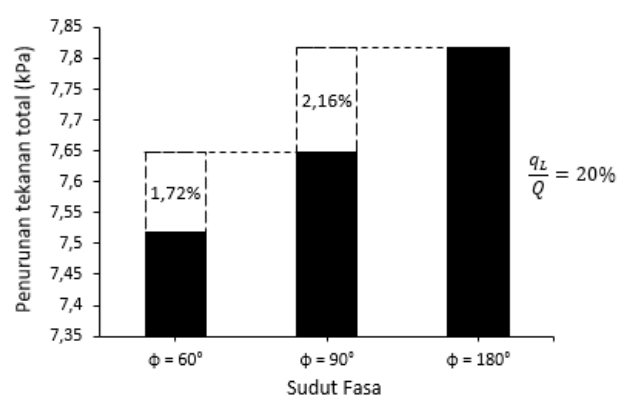

c. Penurunan tekanan total pada flow rate ratio $20 \%$

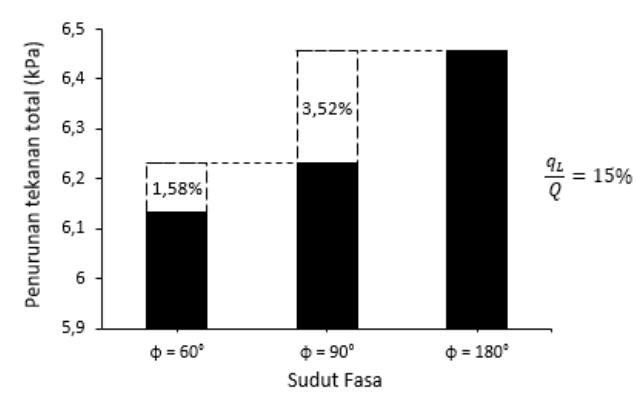

b. Penurunan tekanan total pada flow rate ratio $15 \%$

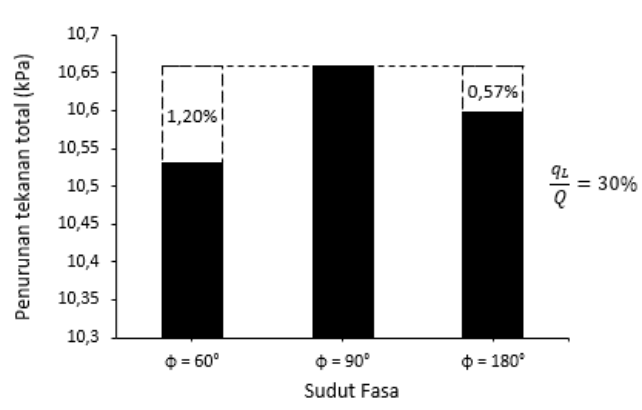

d. Penurunan tekanan total pada flow rate ratio $30 \%$

Gambar 12. Penurunan tekanan total pada sudut fasa

\subsection{Variasi Pola Distribusi Lubang}

Investigasi kedua yang dilakukan adalah pengaruh pola distribusi lubang dengan sudut fasa lubang perforasi $90^{\circ}$. Pola distribusi lubang yang akan dilakukan perbandingan adalah staggered model screw, staggered model non-screw dan non-staggered (posisi lubang sejajar). Jarak antar lubang mulai dari ujung pipa adalah sama besar pada masing-masing baris lubang. Geometri masingmasing pola distribusi lubang ditunjukkan pada Gambar 13.

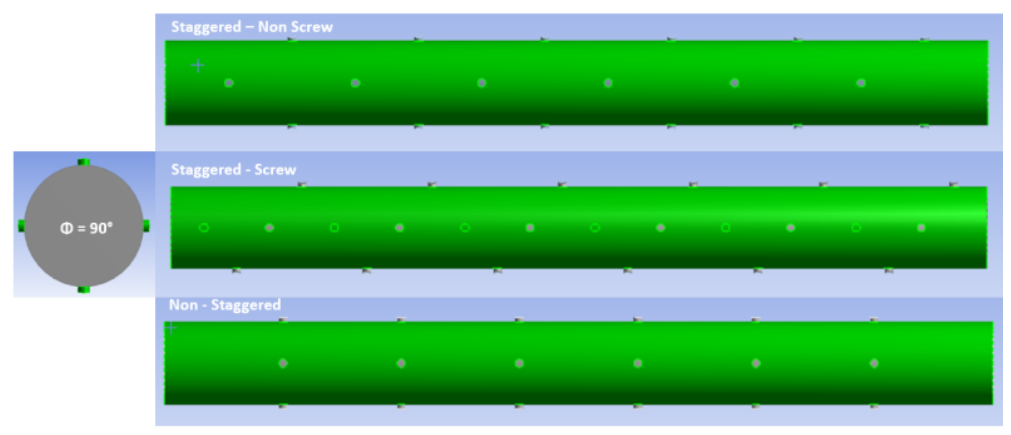

Gambar 13. Pola distribusi lubang

Gambar 14 adalah grafik perbandingan masing-masing komponen penurunan tekanan untuk variasi pola distribusi lubang dengan sudut fasa lubang perforasi dan perforation density yang sama. 


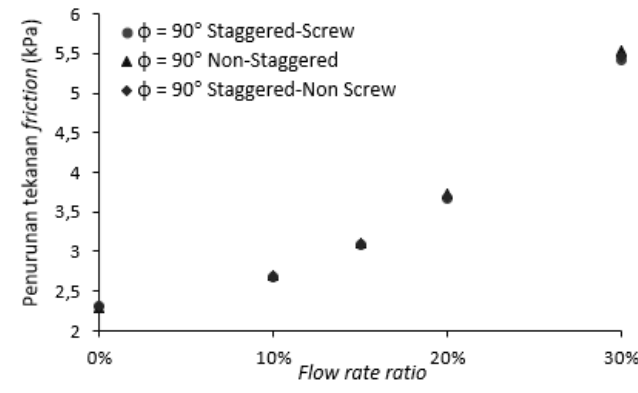

a. Grafik penurunan tekanan friction.

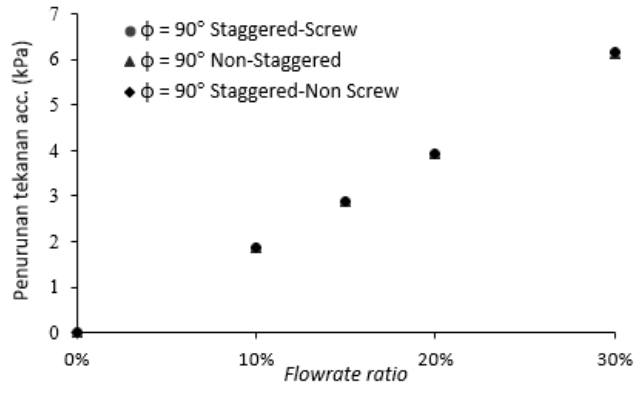

b. Grafik penurunan tekanan acceleration.

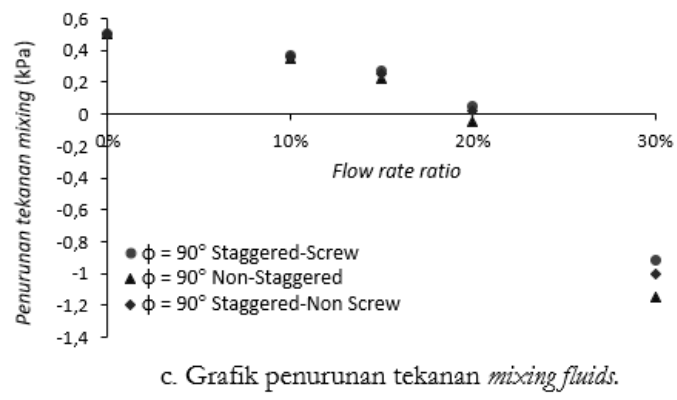

Gambar 14. Penurunan tekanan friction, acceleration dan mixing fluids pada variasi pola distribusi lubang

Pada kondisi flow rate ratio $0 \%$ (tanpa radial inflow) untuk ketiga pola distribusi lubang memiliki perbedaan penurunan tekanan yang juga saling berdekatan seperti pada variasi sudut fasa atau rata-rata sebesar $0,07 \%$ karena memiliki perforation density yang sama. Dari grafik yang ditunjukkan pada Gambar 14a terlihat bahwa pola distribusi lubang non-staggered memiliki penurunan tekanan friction yang paling tinggi dibandingkan dengan kedua model lainnya tetapi secara keseluruhan tidak berpengaruh signifikan sedangkan pada Gambar 14b untuk penurunan tekanan acceleration adalah sama dengan variasi sudut fasa yaitu linear terhadap flow rate ratio karena acceleration disebabkan oleh perubahan momentum yang hanya dipengaruhi oleh densitas dan kecepatan fluida.

Pengaruh terbesar pada variasi pola distribusi lubang perforasi adalah penurunan tekanan mixing fluids. Pada Gambar 14c terlihat bahwa semakin besar flow rate ratio maka semakin kecil penurunan tekanan mixing fluids yang terjadi. Critical limit pada variasi pola distribusi lubang adalah sama dengan critical limit pada variasi sudut fasa yaitu terjadi pada flow rate ratio $20 \%$ karena geometri pipa memiliki perforation density yang sama. Penurunan tekanan mixing fluids setelah melewati critical limit memiliki nilai negatif yang mengindikasikan bahwa radial inflow menurunkan penurunan tekanan total. Pada Gambar 14c juga menunjukkan bahwa pola distribusi lubang model non-staggered memiliki efek mixing yang paling rendah dan hal ini sesuai dengan profil kecepatan main flow di dalam pipa berlubang yang mengalami perubahan akibat adanya radial inflow.

Pada Gambar 15 memperlihatkan profil kecepatan untuk pola distribusi lubang staggered baik model screw maupun non-screw terlihat sama sementara untuk pola distribusi lubang model nonstaggered grafik profil kecepatan terlihat naik turun atau bergelombang akibat pengaruh radial inflow yang bertabrakan dengan main flow di dalam pipa sesuai dengan distribusi lubang perforasinya. Hal ini dikarenakan geometri dari pola distribusi lubang non-staggered yang semua lubangnya sejajar dan saling berhadapan di sekeliling pipa pada jarak yang sama yaitu setiap 0,143 
$\mathrm{m}$ disepanjang pipa sementara untuk staggerred-screw lubang perforasi berada pada setiap $0,04 \mathrm{~m}$ dengan posisi lubang tidak ada yang saling berhadapan dengan lubang lainnya di jarak yang sama sedangkan pola distribusi staggered-non screw berada pada setiap 0,077 $\mathrm{m}$ dengan posisi lubang yang berhadapan sebanyak dua lubang di jarak yang sama seperti yang ditunjukkan pada Gambar 13. Dari ketiga pola distribusi lubang dapat dilihat jika jarak antar lubang untuk geometri pola distribusi lubang non-staggered adalah lebih besar dari dua pola lainnya sehingga profil kecepatan pada pipa berlubang dengan sudut fasa dan perforation density yang sama dipengaruhi oleh pola distribusi lubang yang digunakan.
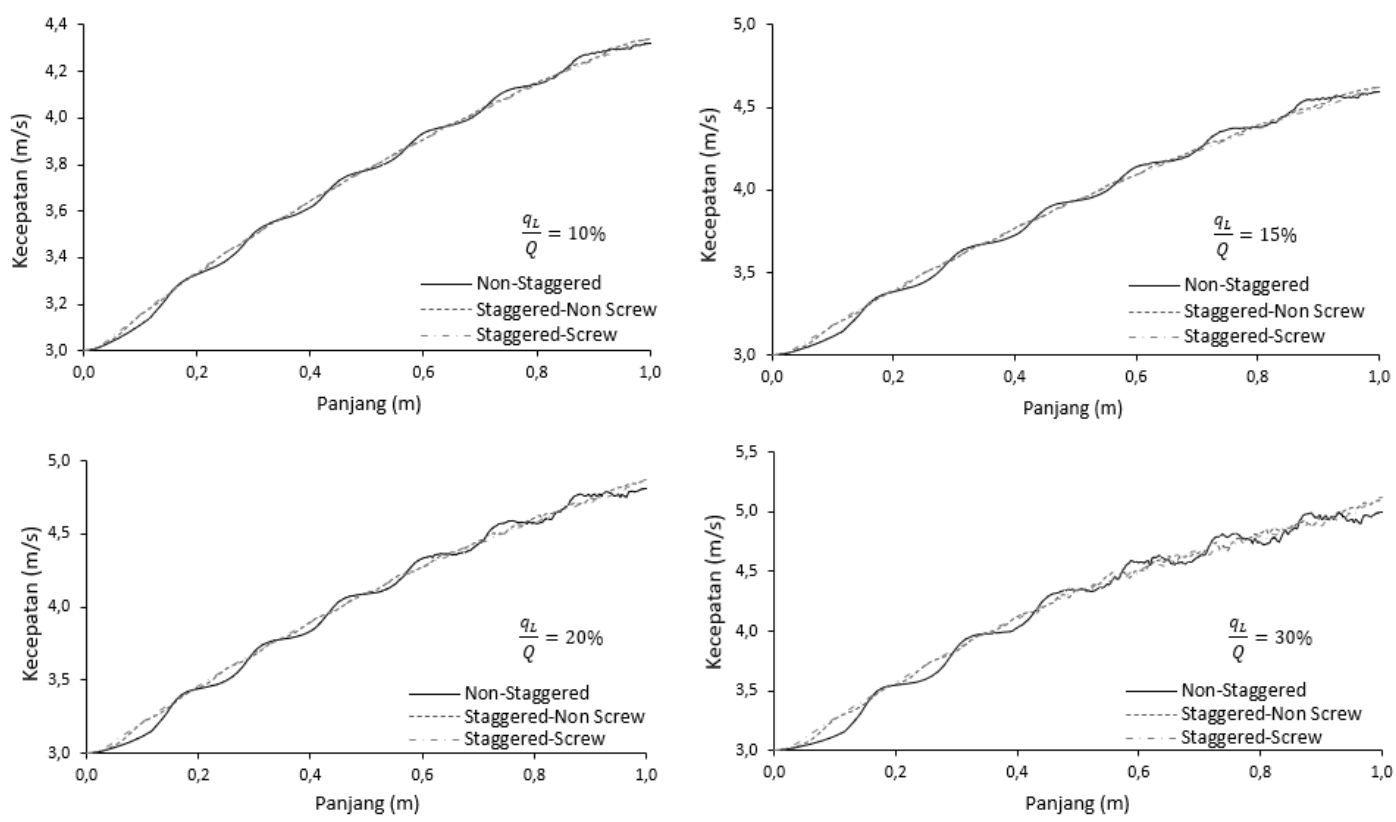

Gambar 15. Profil kecepatan pada masing-masing flow rate ratio

Pada Gambar 16 menunjukkan bahwa pola distribusi lubang non-staggered memiliki penurunan tekanan total yang paling rendah pada masing-masing flow rate ratio. Meskipun pola distribusi non-staggered memiliki penurunan tekanan friction yang lebih tinggi dari kedua pola distribusi staggered (screw dan non screw) tetapi pengaruh penurunan tekanan mixing fluids seperti yang ditunjukkan pada Gambar 14c menyebabkan penurunan tekanan total pada pola distribusi lubang non-staggered. 


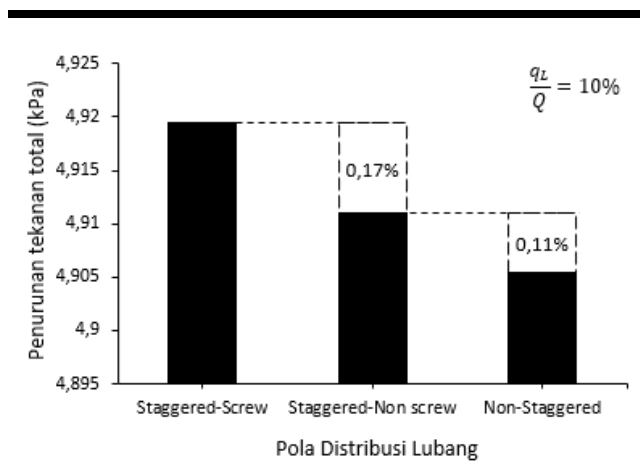

a. Penurunan tekanan total pada flow rate ratio $10 \%$

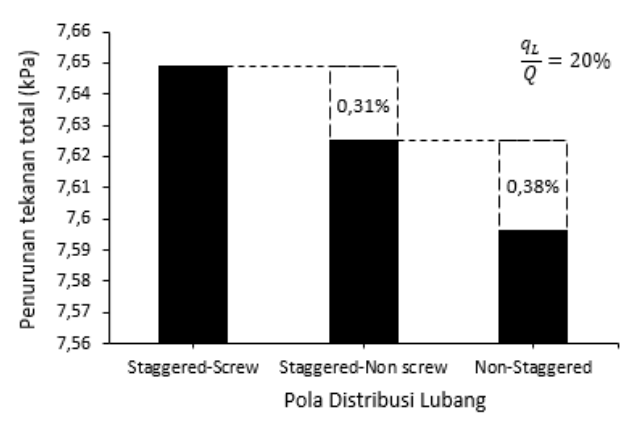

c. Penurunan tekanan total pada flow rate ratio $20 \%$

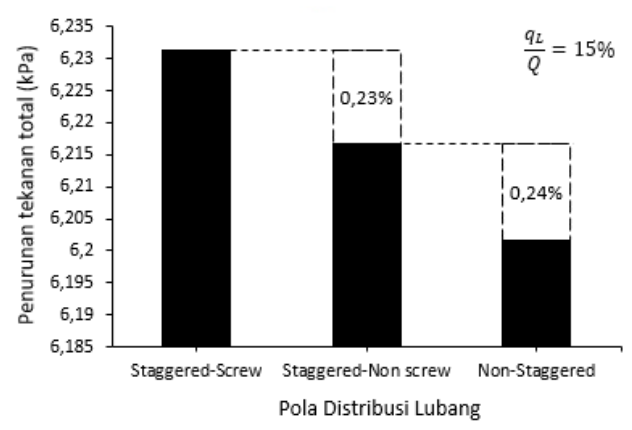

b. Penurunan tekanan total pada flow rate ratio $15 \%$

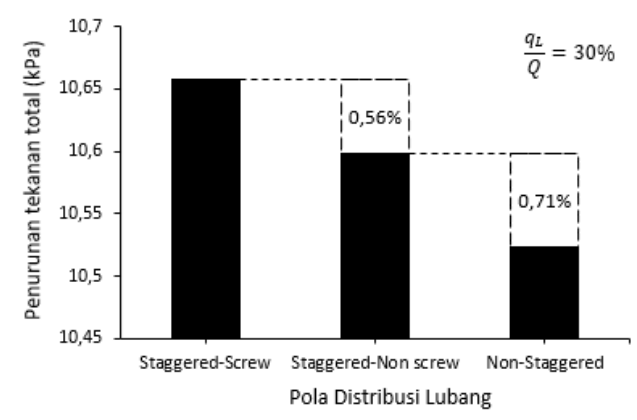

d. Penurunan tekanan total pada flow rate ratio $30 \%$

Gambar 16. Penurunan tekanan total pada pola distribusi lubang

\section{KESIMPULAN}

Dari hasil simulasi untuk karakteristik aliran fluida secara axial flow dan radial inflow yang melalui pipa berlubang sebagai ilustrasi aliran fluida di dalam sumur horisontal maka diperoleh kesimpulan sebagai berikut:

1. Pengaruh sudut fasa lubang perforasi terhadap penurunan tekanan total:

- Pada kondisi tidak ada radial inflow (flow rate ratio 0\%) ketiga sudut fasa lubang perforasi memiliki perbedaan penurunan tekanan total rata-rata sebesar $0,08 \%$ dan perbedaan penurunan tekanan total ketiga sudut fasa terhadap pipa biasa (tanpa lubang) pada tiga kondisi kecepatan inlet (axial flow) secara berturut-turut adalah 10,65\%, 8,94\% dan 9,41\%.

- Pada flow rate ratio 10\%,15\%,20\% dan 30\% pengaruh radial inflow menunjukkan sudut fasa $60^{\circ}$ memiliki penurunan tekanan total yang paling rendah dibandingkan dengan sudut fasa $90^{\circ}$ maupun $180^{\circ}$ dan sudut fasa $60^{\circ}$ secara berturut-turut memiliki perbedaan penurunan tekanan total sebesar 3,77\%, 5,10\%, 3,88\% dan 1,20\% terhadap sudut fasa yang memiliki penurunan tekanan total yang paling tinggi. Penurunan tekanan total yang terjadi di dominasi oleh komponen penurunan tekanan mixing fluids dibandingkan dua komponen penurunan tekanan lainnya.

2. Pengaruh pola distribusi lubang perforasi terhadap penurunan tekanan total:

- Pada kondisi tidak ada radial inflow (flow rate ratio $0 \%$ ) ketiga pola distribusi lubang perforasi memiliki perbedaan penurunan tekanan total rata-rata sebesar $0,07 \%$. 
- Pada flow rate ratio 10\%, 15\%, 20\% dan 30\% pengaruh radial inflow menunjukkan bahwa pola distribusi lubang model non-staggered memiliki penurunan tekanan total yang paling rendah dibandingkan dengan pola distribusi lubang kedua model staggered (screw dan non screw) dan pola distibusi lubang non-staggered secara berturut-turut memiliki perbedaan penurunan tekanan total sebesar $0,28 \%, 0,47 \%, 0,69 \%$ dan 1,27\% terhadap pola distribusi lubang yang memiliki penurunan tekanan paling tinggi. Penurunan tekanan total yang terjadi juga di dominasi oleh komponen penurunan tekanan mixing fluids seperti pada variasi sudut fasa.

3. Penurunan tekanan total yang terjadi pada pipa berlubang dengan perforation density yang sama tergantung dari flow rate ratio. Semakin besar flow rate ratio maka semakin besar penurunan tekanan total pada pipa berlubang. Penelitian lebih lanjut terkait hal ini dapat dilakukan dengan mengganti boundary condition untuk mencari diameter lubang yang optimum sesuai desain pipa berlubang yang diinginkan.

\section{DAFTAR PUSTAKA}

Abdulwahid, M. A., Dakhil, S. F., Niranjan Kumar, I. N., 2013, Numerical Simulation of Flow Through a Wellbore for Horizontal Wells, WIT Transactions on Modelling and Simulation, Vol 55.

Abdulwahid, M. A., Dakhil, S. F., Niranjan Kumar, I. N., 2013, Numerical Investigation of The Turbulent Flow Parameters Distribution in A Partly Perforated Horizontal Wellbore, European Scientific Journal Vol.9, No.33.

Abdulwahid, M. A., Niranjan Kumar, I. N., Dakhil, S. F., 2014, Influence of Radial Flux Inflow Profile on Pressure Drop of Perforated Horizontal Wellbore, Journal of Energy Resources Technology-136(4):1 7.

Ansys Inc., 2018, ANSYS Workbench User's Guide, ANSYS.

Asheim, H., Kolnes, J., Oudeman, P., 1992. A Flow Resistance Correlation for Completed Wellbore, J. Petrol. Sci. Eng. 8 (2).,97-104.

Azadi, M., Aminossadati, S. M., Chen, Z., 2017, Development of an Integrated ReservoirWellbore Model to Examine the Hydrodynamic Behaviour of Perforated Pipes, Journal of Petroleum Science and Engineering.

Dikken, B. J., 1990, Pressure Drop in Horizontal Wells and Its Effect on Production Performance, JPT, November, pp. 1426-1433.

Haaland, S. E., 1983, Simple and Explicit Formulas for the Friction Factor in Turbulent Pipe Flow, Journal of Fluids Engineering 10: 589-590.

Jianguang, W., Xuesong, L., Xuemei, L., Yuanyuan, M., 2017, The Experimental and Model Study on Variable Mass Flow for Horizontal Wells with Perforated Completion, Journal of Energy Resource Technology.

Ouyang, L. B., Arbabi, S., Aziz, K., 1998, A Single-Phase Wellbore-Flow Model for Horizontal, Vertical, and Slanted Wells, SPE-Journal, 3(2):124 133.

Ouyang, L. C., Sun, D., Ouyang, L. B., 2009, Numerical Investigation of the Impacts of Wall Fluid Entry on Fluid Flow Characteristics and Pressure Drop along a Wellbore, Petroleum Science and Technology, 27:18, 2109-2133.

Rashad, Z, M., Abdulwahid, M., Abdulhassan, Q., 2018, Comparison of Pressure Drop in Horizontal Wellbore for $90^{\circ}$ and $180^{\circ}$ Perforation Phasing, Seventh International Conference on Advances in Civil, Structural and Mechanical Engineering - CSM 2018. 
F. M. Tangdan dan T. A. Rohmat / Journal of Mechanical Design and Testing 3(1), (2021), 29-46

Salim, M. K., Sultan, H. S., Al-Shara, A. K. M., 2017, Effect of Shape and Parameters of Perforation in a Vertical Wellbore with Two Perforations (Without Porous Media) on Pressure Drop, Fluid Mech Open Acc 4: 162.

Su Z., Gudmundsson J. S., 1998, Perforation Inflow Reduces Frictional Pressure Loss in Horizontal Wellbores, Journal of Petroleum Science and Engineering.

Su, Z., Gudmundsson, J. S., 1993, Friction Factor of Perforation Roughness in Pipes, SPE26521.

Su, Z., Gudmundsson, J. S., 1994, Pressure Drop in Perforated Pipes: Experiments and Analysis, SPE28800:563 574. 